Игровая продуктивная технология как средство формирования социальной компетентности воспитанников

Крицкая Н.В. ${ }^{a}$, Левчук 3.К. ${ }^{b}$

УО «Витебский государственный университет имени П.М. Машерова»,

Витебск, Республика Беларусь.

a ORCID: https://orcid.org/0000-0001-8569-9137, e-mail: Krickaya74@mail.ru

b ORCID: https://orcid.org/0000-0001-7605-7335

Резюме: В статье рассматривается игровая продуктивная технология как педагогическое средство, ориентированное на самостоятельно созданный воспитанником продукт. Перед современным педагогом стоит задача всестороннего развития умений и навыков детей определенной возрастной группы и обеспечение способности социализироваться в современном обществе. Именно игровая продуктивная технология выступает ориентиром стратегии и тактики педагогической деятельности по формированию социальной компетентности у детей раннего и дошкольного возраста. Цель статьи - рассмотреть принципы, которые играют важную роль в формировании социальной компетентности детей дошкольного возраста. Материал и методы. Методологическую базу исследования составляют работы отечественных и зарубежных ученых и методистов, посвященные проблеме формирования социальной компетентности детей раннего и дошкольного возраста. Материалом для исследования стала система воспитания и обучения в учреждениях дошкольного образования. Объектом настоящего исследования является процесс формирования социальной компетентности воспитанников средствами игровой продуктивной технологии. В статье использовались: метод педагогического наблюдения, моделирования. Делается вывод о том, что при использовании игровых продуктивных технологий, наблюдаются позитивные изменения социального развития детей и фрормирования их социальной компетентности.

Ключевые слова: социальная компетентность, игровая продуктивная технология, учреждения дошкольного образования, основные принципы.

Для цитирования: Крицкая Н.В. Игровая продуктивная технология как средство формирования социальной компетентности воспитанников / Н.В. Крицкая, З.К. Левчук // Развитие образования. - 2019. - № 4 (6). - С. $38-41$. DOI:10.31483/r-63800.

\title{
Productive Game Technology as a Means of Pupils' Social Competence Formation
}

\author{
Natalya V. Kritskayaa , Zoya K. Levchuk \\ El "Vitebsk State University named after P.M. Masherov"', \\ Vitebsk, Republic of Belarus. \\ a ORCID: https://orcid.org/0000-0001-8569-9137, e-mail: Krickaya74@mail.ru \\ b ORCID: https://orcid.org/0000-0001-7605-7335
}

\begin{abstract}
The article considers productive game technology as a pedagogical means focused on a product independently created by a pupil. The modern teacher is faced with the task of comprehensive skills development of children of a certain age group and ensuring the ability to socialize in modern society. It is productive game technology that acts as a reference point for the strategy and tactics of pedagogical activity in the formation of social competence in children of early and preschool age. The purpose of the article is to consider principles which play important role in the formation of preschoolers' social competence. Material and methods. The methodological base of the study is the work of domestic and foreign scientists and methodologists on the problem of the social competence formation of children of early and preschool age. The system of education and teaching in preschool educational institutions was applied as the material for the study. The object of the study is the process of pupils' social competence formation by means of productive game technology. During the study the following methods were applied: the method of pedagogical observation, modeling. It is concluded that applying productive game technology, positive changes in children's social development and their social competence formation can be noticed.
\end{abstract}

Keywords: productive game technology, social competence, preschool educational institutions, main principles.

For citation: Kritskaya N.V., \& Levchuk Z.K. (2019). Productive Game Technology as a Means of Pupils' Social Competence Formation. Razvitie obrazovaniya = Development of education, 4(6), 38-41. (In Russ.) DOI:10.31483/r-63800.

\section{Продукциллӗ вӑйӑ технологийӗ - ӑс илекенсен с̧ынсемпе хутшӑнӑва кӗме пултараслӑхне калӑпламалли мел}

Крицкая Н.В. ${ }^{\text {, }, ~ Л е в ч у к ~ 3 . К . ~}$

П.М. Машеров яче̌лле̌ Витебск патшалӑх университече̌,

Витебск, Беларусь Республики.

a ORCID: https://orcid.org/0000-0001-8569-9137, e-mail: Krickaya74@mail.ru

b ORCID: https://orcid.org/0000-0001-7605-7335

Аннотаци: Статьяра продукцилле̌ вӑйӑ технологине ача саче̌н воспитаннике̌ хӑй те̌лле̌н тӑвакан продукцие те̌пе хуракан педагогика меле̌ тесе тишкерне̌. Авторсем продукцилле̌ вӑйӑ технологийе̌ педагогика е̌с̧е̌н чи ке̌с̧е̌н 
тата шкул уме̌нхи ӱсе̌мре ачасене хутшӑнма хӑнӑхтаракан стратегийе̌пе тактикине тытса пымалли ориентир пулса тӑрать тесе палӑртас̧с̧е̌.

Стаьян те̌ллеве̌ - шкул уме̌нхи ӱсе̌мре ачасен хутшӑну хӑнӑхӑвне калӑпланӑ чухне ме̌нле принципсем те̌п вырӑнта тӑнине кӑтартасси.

Ку те̌пчеве̌н паян кунхи с̧иве̌чле̌хе̌ хальхи педагогӑн пе̌р-пе̌р ӳсе̌мри ачасен ме̌н те пулин тума пултарас хӑнӑхӑвне аталантарассинчен тата хальхи обществӑра кирле̌ пек хутшӑнма юрӑхлӑ тӑвас задача пурринчен тухса тӑрать.

Материал тата меслетсем. Те̌пчеве̌н методика нике̌сне тӑван тата тӑван мар с̧е̌р-шыв ученӑйе̌сен ачасене чи ке̌с̧е̌н тата шкул уме̌нхи у̌се̌мре обществӑра хутшӑнса пурӑнма ве̌рентекен е̌с̧е̌сене хунӑ. Те̌пчев материале̌ шкулчченхи ве̌ренӳ учрежденийе̌сен ве̌рентӱпе воспитани системи пулса тӑрать. Те̌пчев объекче̌ - ачасен с̧ынсемпе хутшӑнас компетенцийе̌ продукцилле̌ вӑйӑ технологийӗпе калӑпланни. Статьяра педагогикӑн сӑнав тата е̌лке̌лев меслече̌семпе усӑ курнӑ.

Результатсем тата ве̌сене сӳтсе явни. Авторсем продукцилле̌ вӑйӑ технологийӗн шкулчченхи ӱсе̌мре ачасен ве̌ренўпе ăс илў шайне кӑтартакан тапхӑре̌сене се̌нне̌. С̧акнашкал методикӑпа усӑ курнине ачасен с̧ынсемпе хутшӑннӑ чухнехи ырӑ аталанӑве̌ тата хутшӑну компетенцийӗ йе̌ркеленсе с̧итнипе е̌нентерме пулать.

Tӗп сӑмахсем: технологи, продукцилле̌ вӑйӑ технологийе̌, с̧ын ыттисемпе пе̌рле чухне хӑйне йе̌ркелле̌ тытма пе̌лни.

Цитатӑлама: Крицкая Н.В. Игровая продуктивная технология как средство формирования социальной компетентности воспитанников / Н.В. Крицкая, З.К. Левчук // Развитие образования. - 2019. - № 4 (6). - С. $38-41$. DOI:10.31483/r-63800.

\section{Введение}

$\mathrm{C}$ овременная белорусская система образования проходит последовательное и конструктивное реформирование, и поэтому затрагивает предметные, методические и содержательные стороны. Компетентностный подход подразумевает формирование у воспитанников учреждений дошкольного образования социальной компетенции. Развитие вышеназванной компетенции является весьма значимой психолого-педагогической проблемой, решение которой затрагивает многие вопросы психологии, образования и всего общества.

Цель данной статьи - показать, какие принципы являются определяющими в формировании социальной компетентности детей дошкольного возраста.

Актуальность настоящего исследования определяется тем, что перед современным педагогом стоит задача всестороннего развития умений и навыков детей определенной возрастной группы и обеспечение способности социализироваться в современном обществе.

Материал и методы. Методологическую базу исследования составляют работы отечественных и зарубежных ученых и методистов, посвященные проблеме формирования социальной компетентности детей раннего и дошкольного возраста. Материалом для исследования стала система воспитания и обучения в учреждениях дошкольного образования. Объект настоящего исследования - процесс формирования социальной компетентности воспитанников средствами игровой продуктивной технологии. В статье использовались метод педагогического наблюдения, моделирования.

Особое место в процессе формирования социальной компетентности детей раннего и дошкольного возраста занимает игровая деятельность. И в педагогике, и в психологии игра существует для стимулирования творческой активности воспитанников и формирования у них навыков поведения в обществе.

В настоящее время огромный интерес для педагогов представляет игровая продуктивная технология. В данном исследовании игровая продуктивная технология понимается как конструирование творческого процесса на основе личностно ориентированной модели, игровых педагогических средств и форм организации, методики их проведения и моделирования, диагностико-коррекционного и оценочного инструментария с целью достижения конечного продукта деятельности ребенка. Особое место в технологии отводится самостоятельной игровой продуктивной деятельности детей, которая организуется посредством системы сюжетных дидактических игр [1].

Термин «игровая» выявляет ориентацию игровой продуктивной технологии на игровую форму организации и игровые педагогические средства, основным из которых является сюжетная дидактическая игра. Она применяется как основа сюжетно-игрового комплекса, игровое педагогическое средство, форма организации творческого процесса, средство и метод диагностики сформированности социальной компетентности воспитанников, средство коррекции содержания воспитательного процесса.

Термин «продуктивная» в данной технологии - это преимущество продуктивной деятельности детей в отличие от репродуктивной, исполнительской деятельности, ориентированный на самостоятельно созданный ребенком продукт.

Игровая продуктивная технология базируется на ряде основных принципов. Во-первых, это принцип ориентации на индивидуальность ребенка, который предусматривает организацию обучения и развития детей дошкольного возраста на новых приоритетах. Главное здесь самовыражение и полное раскрытие творческих возможностей и способностей ребенка.

Педагог и ребенок вступают в партнерские отношения в игре и в решении проблемных ситуаций. Педагог направляет и адаптирует воспитательно-образовательный процесс, учитывая прошлый опыт собственный и детей, поощряет проявление интуиции, находчивость и самостоятельность воспитанников в процессе взаимодействия и сотрудничества.

Таким образом, реализация принципа ориентации на индивидуальность ребенка осуществляется в единстве культурологического, личностно ориентированного и деятельностного подходов, составляющих методологию гуманистической педагогики.

Второй принцип - это принцип эмоционального сопереживания и предвосхищения продукта характеризу- 
ется эмоциональным отношением ребенка к игровому образу, игровому сюжету, образовательному материалу, чувственным переживанием игровой проблемной эмоционально-образной ситуации. Данный принцип предполагает прежде всего передачу педагогом содержания образования на чувственно-эмоциональном уровне, что делает его актуальным для ребенка, вызывает ответное эмоциональное сопереживание.

У субъекта необходимость обращения к чувствам возникает тогда, когда появляется проблема. Для решения интеллектуальной проблемы ее необходимо трансформировать в проблему эмоциональную. Решение эмоциональной проблемы заключается в сугубо индивидуальном отношении личности к происходящему.

Третий принцип - принцип продуктивности деятельности дошкольников, который выступает показателем реализации в воспитательно-образовательном процессе гуманистической парадигмы. Он включает источники, средства, формы организации игры. Данный принцип ориентирует не на предоставление воспитанником знаний в готовом виде, а на создание условий для их приобретения в самостоятельной продуктивной деятельности.

Согласно принципу продуктивности деятельности в педагогическом процессе возможно логическое сочетание творчества, обучения, интеллектуально-поисковой деятельности.

Стратегия развития детей дошкольного возраста средствами игровой продуктивной технологии определена как развитие личностного, в том числе креативного, потенциала ребенка. Креативность рассматривается в личностном аспекте как внутренний компонент продуктивной деятельности. Система целей выявляет возможность достижения педагогом гарантированного результата игровой продуктивной технологии.

Основная цель педагогической деятельности в игровой продуктивной технологии - это социальное развитие воспитанника. Она раскрывается в спектре целевых ориентации, который в свою очередь выступает предметной проекцией будущего, целостного представления о планировании гарантированного результата, а также выявляет суть развивающих, дидактических, воспитательных и социализирующих целей.

В таблице мы предлагаем этапы и направления работы.

Цель игровой продуктивной технологии - развивать у ребенка эмоциональное сопереживание, продуктивное воображение, интуицию, фантазию, потребности в самопознании, самоутверждении, самореализации; научить воспитанника самостоятельному применению полученных знаний; воспитывать выдержку, волю, настойчивость, самостоятельность, решительность, находчивость, интерес к сверстникам, чувства доброжелательности, взаимопомощи, поддержки, веры в достижение успеха; приобщать к нравственным и духовным ценностям.

Заключение. Предложенные этапы фактически являются последовательными уровнями воспитательно-образовательной деятельности дошкольников, с постоянными усложняющимися задачами на каждом новом, более высоком уровне развития. Использование такой методики можно будет заметить позитивные изменения социального развития детей, возросший потенциал социальной компетентности, что в целом поможет им успешно адаптироваться к школе. Данный подход эффективен в использовании в воспитательно-образовательном процессе учреждения дошкольного образования.

\begin{tabular}{|c|c|c|c|}
\hline № & Направления в работе & Этап 1 & Этап 2 \\
\hline 1 & $\begin{array}{l}\text { Ориентация ребенка } \\
\text { в нестандартной ситуации }\end{array}$ & $\begin{array}{l}\text { Обыгрывание проблемных ситуаций: } \\
\text { «Гости на пороге» } \\
\text { «Я иду на день рождение к...» } \\
\text { «Мы едем в автобусе» } \\
\text { «Мы пришли в театр» }\end{array}$ & $\begin{array}{l}\text { «Заочная экскурсия по родному городу» } \\
\text { (создается карта города, детям даются } \\
\text { карточки с изображением } \\
\text { достопримечательных мест, они должны } \\
\text { на карте найти, должны выступить в роли } \\
\text { гида) }\end{array}$ \\
\hline 2 & $\begin{array}{l}\text { Планирование собственной } \\
\text { деятельности }\end{array}$ & $\begin{array}{l}\text { «Собери пазл и узнай, что делать } \\
\text { дальше» }\end{array}$ & «Кому и что надо для работы» \\
\hline & $\begin{array}{l}\text { Использование способов } \\
\text { преобразования,изменение } \\
\text { форм, создание по аналогии } \\
\text { и т. п. }\end{array}$ & «Дорисуй картинку» & $\begin{array}{l}\text { «Мастерская по ремонту» (карточки с } \\
\text { рисунком предмета, но в ней есть ошибка, } \\
\text { «починить» предмет - изобразить на } \\
\text { листе рисунок). } \\
\text { Изготовление атрибутики к сюжетно- } \\
\text { ролевой игре (умение преобразовывать } \\
\text { из бросового материала предметы } \\
\text { заместители) }\end{array}$ \\
\hline & $\begin{array}{l}\text { Применение знаний } \\
\text { в различных ситуациях }\end{array}$ & $\begin{array}{l}\text { «Поступи правильно» } \\
\text { Создание проблемной ситуации } \\
\text { (что ты будешь делать, если мяч } \\
\text { выкатился на дорогу?) }\end{array}$ & игра «Пожар» \\
\hline & Организация рабочего места & $\begin{array}{l}\text { «Кому что нужно для работы?» } \\
\text { (большие карты с изображением } \\
\text { человека, и маленькие карточки } \\
\text { с орудиями или инструментами) }\end{array}$ & «Накроем стол для гостей» \\
\hline & $\begin{array}{l}\text { Доведение начатого до конца, } \\
\text { умение добиваться результата }\end{array}$ & $\begin{array}{l}\text { «Я начну, а ты продолжи» } \\
\text { «Мы расскажем и покажем» } \\
\text { «Выбери нужное» } \\
\text { «Выдели правильно» }\end{array}$ & \\
\hline
\end{tabular}




\section{Список литературы}

1. Ходонович Л.С. Игровая продуктивная технология развития музыкального творчества дошкольников: педагогическое пособие для педагогов учреждений, обеспечивающих получение дошкольного образования / Л.С. Ходонович. - Минск: Зорны верасень, 2007. - 168 с.

\section{References}

1. Khodonovich, L. S. (2007). Igrovaia produktivnaia tekhnologiia razvitiia muzykal'nogo tvorchestva doshkol'nikov: pedagogicheskoe posobie dlia pedagogov uchrezhdenii, obespechivaiushchikh poluchenie doshkol'nogo obrazovaniia., 168. Minsk: Zorny verasen'.

\section{Информация об авторе} Крицкая Наталья Викторовна канд. филол. наук, доцент, УО «Витебский государственный университет имени П.М. Машерова», Витебск, Республика Беларусь.

\section{Левчук Зоя Климентьевна -} канд. пед. наук, доцент, УО «Витебский государственный университет имени П.М. Машерова», Витебск, Республика Беларусь.
Information about the author Natalya V. Kritskaya -

candidate of philological sciences, associate professor, EI «Vitebsk

State University named after P.M. Masherov», Vitebsk, Republic of Belarus.

Zoya K. Levchuk -

candidate of pedagogic sciences, associate professor, EI «Vitebsk State University named after P.M. Masherov», Vitebsk, Republic of Belarus.
Авторсем суинчен пёлтерни Крицкая Наталья Викторовна филологи ӑслӑлӑхӗн к-че̌, П.М. Машеров яче̌лле̌ Витебск патшалӑх университече̌н доценче̌, Витебск, Беларусь Республики.

Левчук Зоя Климентьевна педагогика ӑслӑлӑхе̌н к-че̌, П.М. Машеров яче̌лле̌ Витебск патшалӑх университече̌н доценче̌, Витебск, Беларусь Республики. 